\title{
Progesterone inhibits glucocorticoid-dependent aromatase induction in human adipose fibroblasts
}

\author{
M Schmidt, C Renner and G Löffler \\ Institut für Biochemie, Genetik und Mikrobiologie, Universität Regensburg, D-93040 Regensburg, Germany \\ (Requests for offprints should be addressed to M Schmidt, LS Biochemie III, Institut für Biochemie, Genetik und Mikrobiologie, Universität Regensburg, \\ D-93040 Regensburg, Germany)
}

\begin{abstract}
In fibroblasts derived from human adipose tissue, aromatase induction is observed after exposure to $1 \mu \mathrm{M}$ cortisol in the presence of serum or platelet-derived growth factor (PDGF). Progesterone suppresses this induction in a dose-dependent manner, $10 \mu \mathrm{M}$ resulting in complete inhibition. A reduced cortisol concentration $(0 \cdot 1 \mu \mathrm{M})$ concomitantly reduces the progesterone concentration required for effective inhibition $(10-100 \mathrm{nM})$. This effect of progesterone is specific, as neither the release of cellular enzymes nor aromatase induction by dibutyrylcAMP, which acts independently from cortisol, are affected. However, the inhibitory effect of progesterone requires its presence throughout the induction period. Kinetic studies in intact cells reveal a reduced number of aromatase active sites upon progesterone treatment,
\end{abstract}

whereas progesterone at near-physiological concentration $(100 \mathrm{nM})$ does not inhibit aromatase activity in isolated microsomes. Semi-quantitative reverse transcriptase PCR analysis shows reduced amounts of aromatase mRNA in progesterone-treated cells, indicating specific inhibition of the glucocorticoid-dependent pathway of aromatase induction. The inhibitory effect of progesterone is not blocked by the anti-progestin ZK114043, excluding action via progesterone receptors and indicating competition for the glucocorticoid receptor. Progesterone must be considered a potential physiological inhibitor of glucocorticoiddependent aromatase induction in adipose tissue. It is proposed that it is a suppressor of aromatase induction in adipose tissue in premenopausal women.

Journal of Endocrinology (1998) 158, 401-407

\section{Introduction}

The enzyme aromatase is responsible for the production of estrogens from androgenic precursors (for review see Simpson et al. 1989, 1994). In premenopausal women it is found mainly in the ovaries and during gestation in the placenta (Meyer 1955, Richards 1994). In men and postmenopausal women, estrogens are produced mainly in fibroblasts from adipose tissue (Simpson et al. 1994). They contain considerable aromatase activity, but its regulation is only partially understood. Glucocorticoids are powerful inducers of aromatase, but their action depends on the presence of serum (Simpson et al. 1981) or serum-derived growth factors like platelet-derived growth factor (PDGF) (Schmidt \& Löffler 1994). Dibutyryl-cAMP (Bu 2 cAMP) is also able to induce aromatase, but this effect is inhibited by serum or serum-derived growth factors (Mendelson et al. 1982, 1986). Gonadotropins, which stimulate estrogen production in ovaries, have no influence on estrogen production in adipose fibroblasts (Simpson et al. 1989).

Aromatase activity in vivo in adipose tissue from healthy donors depends on transcription of the aromatase gene starting from glucocorticoid-dependent promotors (Harada et al. 1993, Mahendroo et al. 1993). Therefore glucocor- ticoid action is a prerequisite for estrogen production in adipose tissue. At present, there is little knowledge about physiological mechanisms that may inhibit the glucocorticoid-dependent pathway of aromatase induction in adipose fibroblasts. However, the increased rates of estrogen synthesis in adipose tissue from older (Hemsell et al. 1974) or obese (MacDonald et al. 1978) patients could be caused by either the enhanced action of inducers or a loss of inhibitors in these patients.

We report here that progesterone inhibits the glucocorticoid-dependent, but not the cAMP-dependent, pathway of aromatase induction in human adipose fibroblasts in vitro. We provide evidence that this inhibition is at the transcriptional level and that it results from the interaction of progesterone with the glucocorticoid receptor.

\section{Materials and Methods}

\section{Materials}

Cell culture media, fetal calf serum (FCS), antibiotics, trypsin solution and collagenase were purchased from Biochrom (Berlin, Germany), BSA from Biomol 
(Hamburg, Germany), HEPES, biotin, Norit A, dextran and Serva Blue G-250 from Serva (Heidelberg, Germany), and cortisol, progesterone, transferrin and pantothenate from Sigma (Deisenhofen, Germany). Recombinant human PDGF-BB was obtained from BTS (St Leon-Rot, Germany). $\left[1 \beta, 2 \beta-{ }^{3} \mathrm{H}\right]$ Testosterone was from NEN/ DuPont (Dreieich, Germany). RNeasy columns came from Qiagen (Hilden, Germany), RNasin from Promega (Mannheim, Germany), Moloney murine leukemia virus (MMLV) reverse transcriptase (RT) from Amersham (Braunschweig, Germany), Taq DNA polymerase from PAN Systems (Nürnberg, Germany) and nylon membranes from Appligene (Heidelberg, Germany). All other molecular biology reagents, including the DIG labeling and detection systems were from Boehringer-Mannheim (Mannheim, Germany). Insulin was a gift from Dr Brocks, Farbwerke Hoechst AG (Frankfurt, Germany). ZK114043 was kindly provided by Dr Parczyk, Schering AG (Berlin, Germany). All other reagents were of analytical grade and were obtained from Merck (Darmstadt, Germany).

\section{Cells and cell culture}

Human adipose tissue for the preparation of adipose fibroblasts was obtained during plastic breast surgery from healthy women. The donors gave informed consent according to a protocol, which was approved by the Ethikkommission of the University of Regensburg. Cells were isolated as described (Schmidt \& Löffler 1997) and were subcultivated after treatment with $0 \cdot 25 \%$ trypsin in PBS; the detached cells were diluted with medium and placed in 24-well plates or 100-mm dishes (for RNA isolation) and grown as described previously (Schmidt \& Löffler 1997). For pretreatment before aromatase induction, the confluent monolayers were washed free of serum constituents and incubated for $48 \mathrm{~h}$ with serum-free medium (SF-medium), with replacement of the medium after $24 \mathrm{~h}$. SF-medium consisted of Dulbecco's modified Eagle's medium and Ham's F12 medium in a ratio of 3:1 (both without phenol red) supplemented with penicillin (100 U/ml), streptomycin $(0 \cdot 1 \mathrm{mg} / \mathrm{ml})$, transferrin $(2 \mu \mathrm{g} /$ $\mathrm{ml})$, pantothenate $(17 \mu \mathrm{M})$, biotin $(1 \mu \mathrm{M})$ and insulin $(1 \mathrm{nM})$. Culture conditions included a humidified atmosphere with $5 \% \mathrm{CO}_{2}$ at a temperature of $37^{\circ} \mathrm{C}$.

\section{Induction of aromatase and assay of aromatase activity}

After the pretreatment phase, aromatase activity in adipose tissue stromal cells was induced by supplementation of SF-medium with cortisol and either $10 \%$ FCS or $0.5 \mathrm{nM}$ PDGF-BB. Alternatively, $\mathrm{Bu}_{2} \mathrm{cAMP}(1 \mathrm{mM})$ was used as inducer in the absence of cortisol and serum. Progesterone and other antagonists were given immediately before induction was started. The total time of induction was $24 \mathrm{~h}$. The substrate for the aromatase enzyme, $[1 \beta, 2 \beta-$ ${ }^{3} \mathrm{H}$ ]testosterone $(38 \mathrm{nM}, 1 \mu \mathrm{Ci} /$ well; with exception of the kinetic experiments), was added $6 \mathrm{~h}$ before the incubation was terminated. Incorporation of ${ }^{3} \mathrm{H}$ into $\mathrm{H}_{2} \mathrm{O}$ was measured essentially as described previously (Ackerman et al. 1981). Aromatase activity is given as pmol testosterone used $/ 6 \mathrm{~h}$ per $\mathrm{mg}$ protein calculated as described by Cole \& Robinson (1990) and experimentally confirmed for our assay in the laboratory. Whole cell protein was determined by an improved protocol of the method of Bradford (1976), as described by Peterson (1983).

\section{Aromatase assay using placental microsomes}

The placental microsomal preparation and the microsomal assay were carried out as described by Kellis \& Vickery (1987).

\section{Assay of lactate dehydrogenase and alkaline phosphatase activities}

Lactate dehydrogenase activity was determined by the procedure of Bergmeyer \& Bernt (1974), and alkaline phosphatase activity as described by Walter \& Schütt (1974). After removal of the supernatant for determination of aromatase activity, the cell layers were washed with PBS and then lysed in $1 \mathrm{ml}$ PBS by sonification. The lysates were centrifuged (13 $500 \mathrm{~g}$; $5 \mathrm{~min}$ ) and directly assayed for enzyme activity and cellular protein content.

\section{$R T-P C R$ analysis of aromatase expression}

Cells were grown in 100-mm dishes and treated in parallel to the cells used for the aromatase assay. RNA was isolated via RNeasy affinity columns following the manufacturer's instructions. For RT-PCR, $1 \mu \mathrm{g}$ total RNA was reversetranscribed $\left(1 \mathrm{~h} / 37^{\circ} \mathrm{C}\right)$ using $200 \mathrm{U}$ MMLV RT and subsequently amplified with $2 \cdot 5 \mathrm{U}$ Taq DNA polymerase for the given number of cycles $\left(1 \mathrm{~min} / 94^{\circ} \mathrm{C}, 1 \mathrm{~min} /\right.$ $64{ }^{\circ} \mathrm{C}, 30 \mathrm{~s} / 74^{\circ} \mathrm{C}$ ) using the oligonucleotides $5^{\prime}$-ttatgagg agcatgcggtacc (forward) and $5^{\prime}$-tagtgttccagacacctgtc (reverse). After agarose gel electrophoresis and blotting by standard protocols (Sambrook et al. 1989), the PCR products were hybridized with $100 \mathrm{ng}$ of a digoxigeninlabeled probe corresponding to the amplified $432 \mathrm{bp}$ cDNA fragment covering parts of exons 9 and 10 of the aromatase gene and detected using the DIG luminescent detection system according to the manufacturer's instructions. The identity of the cloned fragment used for the generation of the probe was confirmed by sequencing. PCR products were quantified by means of a video densitometer.

\section{Statistical analysis}

Comparative analyses of aromatase activities between pairs of treatment groups were performed using Student's $t$-test 


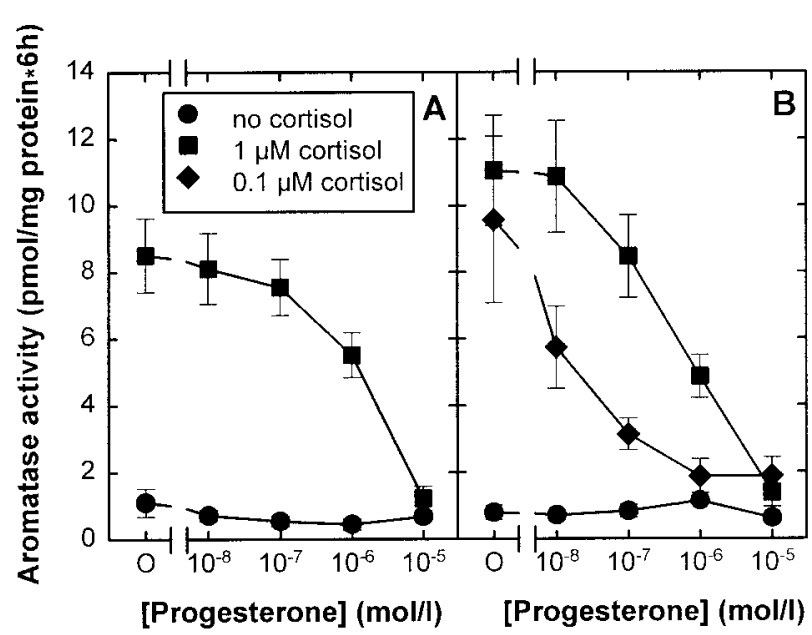

Figure 1 Progesterone inhibits aromatase induction by cortisol. Human breast adipose tissue fibroblasts were incubated for $24 \mathrm{~h}$ without or with cortisol in the presence of $10 \%$ FCS (A) or $0.5 \mathrm{nM}$ PDGF-BB (B) and the given concentrations of progesterone. The results are means \pm S.E.M. from six $(A)$ or five $(B ; 3$ for $0 \cdot 1 \mu \mathrm{M}$ cortisol) preparations of cells, which were assayed in duplicate. Corresponding values obtained in the presence or absence of cortisol are significantly different (Mann-Whitney U-test) in: (1) the presence of $0-1 \mu \mathrm{M}$ progesterone $(P<0 \cdot 005)$ when $1 \mu \mathrm{M}$ cortisol was used for induction; (2) the presence of $0-100 \mathrm{nM}$ progesterone $(P<0 \cdot 01)$ when $0 \cdot 1 \mu \mathrm{M}$ cortisol was used for induction. In the absence of cortisol, progesterone had no significant effect.

or, when the data for one of the treatment groups to be compared were not distributed normally, the MannWhitney U-test. ANOVA was used for comparision of more than two groups.

\section{Results}

Aromatase induction in human adipose fibroblasts is observed after treatment with either FCS or PDGF-BB in the presence of cortisol.

To test the influence of progesterone on estrogen biosynthesis in adipose tissue, adipose fibroblasts were incubated with various concentrations of progesterone immediately before aromatase was induced by addition of cortisol together with either FCS or PDGF-BB. With progesterone in concentrations ranging from $100 \mathrm{nM}$ to $10 \mu \mathrm{M}$, aromatase induction was inhibited in a dosedependent manner. When FCS was used instead of PDBF-BB as a mediator of aromatase induction, the dose-response curve was shifted to the right. About fivefold higher progesterone concentrations are needed to obtain a degree of inhibition comparable to that observed in the presence of PDGF-BB (Fig. 1A and B).

When $0 \cdot 1 \mu \mathrm{M}$ cortisol was used together with $0.5 \mathrm{nM}$ PDGF-BB, the aromatase activities were reduced to about $80 \%$ of those seen after treatment of cells with $1 \mu \mathrm{M}$

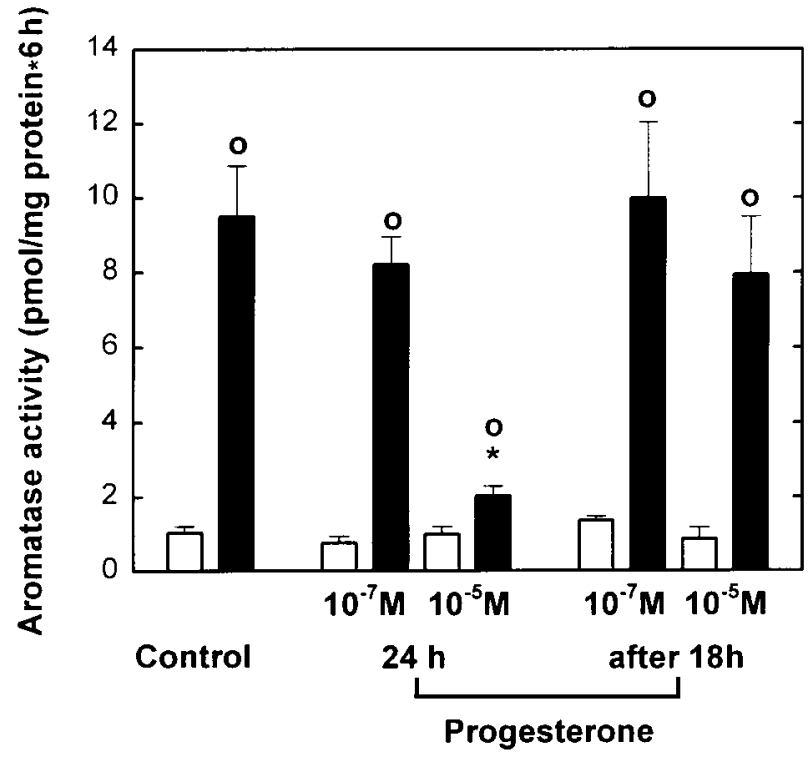

Figure 2 Progesterone action requires its presence throughout the induction period. Adipose fibroblasts were induced with $1 \mu \mathrm{M}$ cortisol and FCS for $24 \mathrm{~h}$. Progesterone was added either during the whole induction period $(24 \mathrm{~h})$ or after $18 \mathrm{~h}$, i.e. during the last $6 \mathrm{~h}$, concomitantly with the radiolabeled aromatase substrate. Data were obtained in the absence (open bars) or presence (solid bars) of cortisol and represent the means \pm S.E.M. from three preparations of cells assayed in duplicate. Differences from the corresponding values in the absence of cortisol (o) or progesterone $\left(^{*}\right)$ are significant $(P<0 \cdot 05$; Mann-Whitney $U$-test).

cortisol. Under these conditions, progesterone was more effective, resulting in almost complete inhibition of aromatase at a concentration as low as $0 \cdot 1 \mu \mathrm{M}$. In the absence of cortisol, there was no effect of progesterone on aromatase induction with either FCS or PDGF-BB.

Release of lactate dehydrogenase and alkaline phosphatase from the cells does not change during the culture period upon treatment with $10 \mathrm{nM}$ to $10 \mu \mathrm{M}$ progesterone (data not shown). Therefore progesterone does not affect overall cell performance, but interacts specifically with the glucocorticoid-dependent pathway of aromatase induction.

When aromatase was induced by treatment of adipose tissue fibroblasts with $\mathrm{Bu}_{2} \mathrm{cAMP}$ instead of cortisol together with either PDGF-BB or FCS, aromatase activity reached $34.8 \pm 5.7 \mathrm{pmol} / 6 \mathrm{~h}$ per $\mathrm{mg}$ protein in the presence of $10 \mu \mathrm{M}$ progesterone, compared with $31 \cdot 4 \pm$ $10.3 \mathrm{pmol} / 6 \mathrm{~h}$ per $\mathrm{mg}$ protein in the absence of progesterone (means \pm s.E.M. from three preparations of cells assayed in duplicate).

To exclude the possibility of direct inhibition of aromatase enzyme activity by progesterone, we studied the time-dependence of the progesterone effect (Fig. 2). In the presence of $1 \mu \mathrm{M}$ cortisol, $10 \mu \mathrm{M}$ progesterone caused almost complete inhibition when present throughout the induction period. However, the addition of even $10 \mu \mathrm{M}$ 


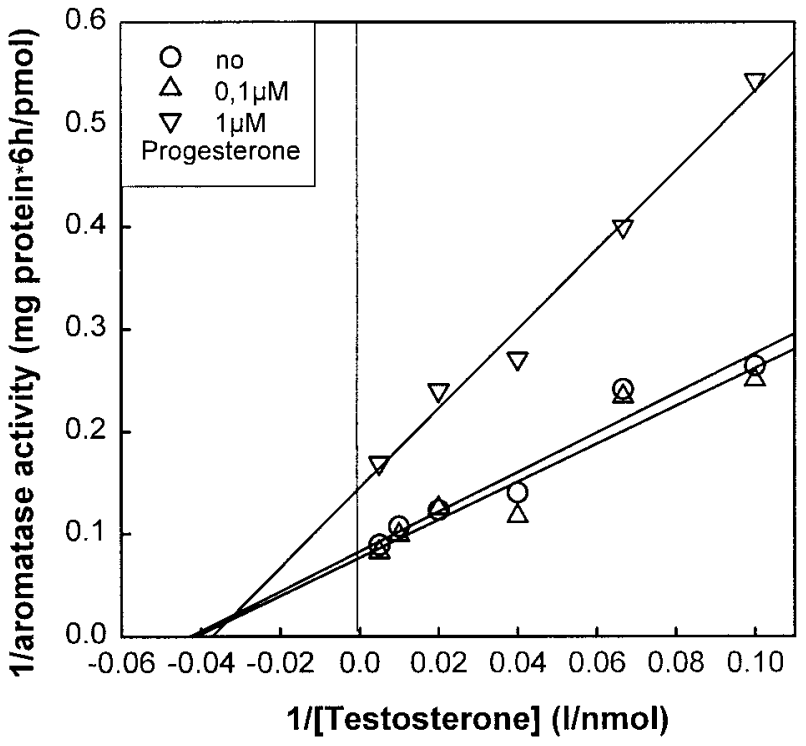

Figure 3 Inhibition of aromatase activity is non-competitive. Lineweaver-Burk plot of aromatase enzyme kinetic measurements on intact adipose fibroblasts induced with $1 \mu \mathrm{M}$ cortisol and PDGF-BB. Data are means from duplicate wells from a representative experiment (out of three). Linear regression analysis reveals no differences in the $K_{\mathrm{m}}$ values obtained for the various progesterone concentrations. Progesterone at a concentration of $1 \mu \mathrm{M}$ caused a reduction in aromatase activity from 14.3 to $6.5 \mathrm{pmol} / 6 \mathrm{~h}$ per mg protein, whereas at $10 \mu \mathrm{M}$ it caused complete inhibition.

progesterone to the cells only for the last $6 \mathrm{~h}$ of the $24 \mathrm{~h}$ induction period elicits only a slight insignificant reduction in aromatase activity.

Similar results were obtained when human placental microsomes were used instead of adipose fibroblasts. The mean \pm S.E.M. of the relative aromatase activities for three preparations of microsomes treated with vehicle only was $100 \pm 2 \cdot 7 \%$, whereas in the presence of $0 \cdot 1 \mu \mathrm{M}$ progesterone it was $105 \cdot 8 \pm 3 \cdot 4 \%$. Progesterone at $0 \cdot 1 \mu \mathrm{M}$ has no effect on placental aromatase activity, even though it blocks aromatase induction almost completely in intact adipose fibroblasts in the presence of $0 \cdot 1 \mu \mathrm{M}$ cortisol (Fig. 1B). The slight, but nevertheless significant $(P<0 \cdot 05)$, inhibitory effect of $10 \mu \mathrm{M}$ progesterone to $87 \cdot 5 \pm 4 \cdot 2 \%$ may indicate a direct inhibitory action of very high doses of progesterone.

The type of inhibition of aromatase activity by progesterone is non-competitive (Fig. 3). At a concentration of $1 \mu \mathrm{M}$ cortisol and $0.5 \mathrm{nM}$ PDGF-BB, no change in $K_{\mathrm{m}}$ (25 nM) was observed, whereas the $V_{\max }$ decreased (from 14.3 to $6.5 \mathrm{pmol} / 6 \mathrm{~h}$ per $\mathrm{mg}$ protein in the presence of $1 \mu \mathrm{M}$ progesterone for the experiment shown).

Semi-quantitative RT-PCR analysis revealed a significant reduction in aromatase mRNA in adipose fibroblasts treated with $10 \mu \mathrm{M}$ progesterone in the presence of PDGF-BB and cortisol compared with control cells with- out progesterone treatment (Fig. 4). The remaining aromatase mRNA was in the range from almost undetectable to about $25 \%$ and varied between different preparations of cells.

To gain further insight into the mechanism of the progesterone effect, we tested the influence of an anti-progestin without anti-glucocorticoid properties, ZK114043 (Li et al. 1995), on aromatase induction (Table 1). It did not block the progesterone effect on aromatase induction and proved to be a weak aromatase inhibitor.

\section{Discussion}

Little is known about the physiological regulators of extra-ovarian and extraplacental estrogen production. In fibroblasts from human adipose tissue, induction of the aromatase gene by cortisol has been described (Simpson et al. 1994), which depends on the presence of serum or serum-derived growth factors (Schmidt \& Löffler 1994). $\mathrm{Bu}_{2} \mathrm{cAMP}$ also causes induction of the aromatase gene, but its effect is strongly inhibited by serum or PDGF-BB (Mendelson et al. 1982, 1986, Schmidt \& Löffler 1994).

Our finding of progesterone inhibition of aromatase gene expression adds a new regulatory mechanism. Kinetic analysis indicates that progesterone has no effect on $K_{\mathrm{m}}$ but reduces the $V_{\max }$ of the aromatase enzyme. A plausible explanation for this finding is that the number of active enzyme molecules is reduced by progesterone. Since progesterone is ineffective when added during the final $6 \mathrm{~h}$ of the induction period, we conclude that it is not a direct inhibitor of the aromatase enzyme. This conclusion is supported by the finding that progesterone has no inhibitory effect on the aromatase activity of isolated placental microsomes.

Previous work (Evans et al. 1987) has shown that aromatase activity is regulated mainly at the transcriptional level. As measured by semi-quantitative RT-PCR analysis, the amount of aromatase mRNA is reduced under the influence of progesterone. This indicates that progesterone inhibits the transcription of the aromatase gene or stimulates the breakdown of its mRNA. Determination of the relative mRNA contents of adipose fibroblasts does not allow us to distinguish between these alternatives. However, taking into account the considerations discussed below, we conclude that progesterone indeed inhibits transcription of the aromatase gene.

There are two different ways by which progesterone could regulate transcription: it could act via progesterone receptors or by interaction with the glucocorticoid receptor. Progesterone receptors have so far been detected in the adipose tissue of animal species such as sheep and rat, but not in human adipose tissue from various locations (Rebuffe-Scrive et al. 1990). In undissociated human adipose tissue slices, progesterone had no detectable effect on the expression of the progesterone-regulated 

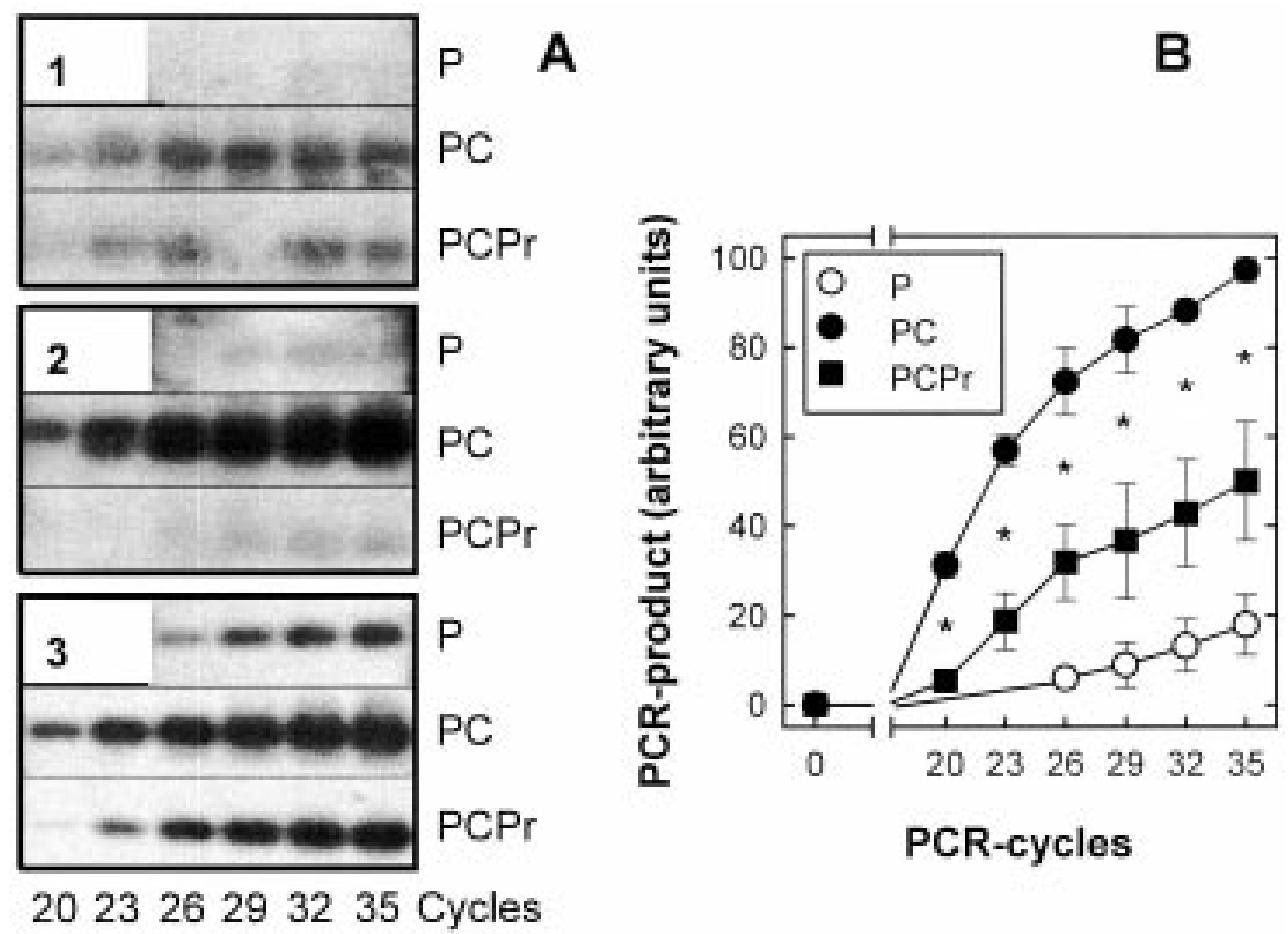

Figure 4 Aromatase mRNA levels are reduced in progesterone-treated cells. Semi-quantitative RT-PCR analysis of aromatase mRNA content of adipose fibroblasts after $24 \mathrm{~h}$ treatment with $0.5 \mathrm{nM}$ PDGF (P), 0.5 $\mathrm{nM}$ PDGF and $1 \mu \mathrm{M}$ cortisol (PC) or 0.5 nM PDGF, $1 \mu \mathrm{M}$ cortisol and $10 \mu \mathrm{M}$ progesterone (PCPr). Starting from $1 \mu \mathrm{g}$ total RNA for each condition, RT-PCR was performed as described in Materials and Methods. Equal volumes of PCR mixture were analyzed on the same gel, membrane and film simultaneously. (A) The amount of reduction in aromatase mRNA content of stromal cells after treatment with progesterone is variable and depends on the preparations of cells used (marked 1, 2 and 3). With RNA from cells treated with progesterone, at least three additional cycles are necessary to detect the same amount of PCR product as found in the absence of progesterone (1). In another sample, only traces of PCR product were detected even after 35 cycles (2). For a better comparison, lanes containing PCR products obtained after identical numbers of cycles were placed in vertical rows. The PDGF-only values for 20 and 23 cycles were not determined, because a clear signal was not obtainable under these conditions in initial experiments. (B) The blots shown in (A) and from an additional experiment were quantified densitometrically. Resulting values for signal intensity were normalized and plotted against number of cycles. There is a significant difference between corresponding amounts of PCR products obtained in the absence or presence of progesterone (Student's $t$-test, $P<0 \cdot 05$ ). Note that the exponential product accumulation occurs only in the range below 30 arbitrary units.

metallothionein gene (Brönnegard et al. 1994). As adipose fibroblasts represent only a small fraction of cells from adipose tissue (when measured by volume or mass), this does not exclude the possibility that minute amounts of progesterone receptors, which are below the detection limit in whole tissue preparations, are present only in fibroblasts from human adipose tissue. However, recently this issue was directly adressed in adipose fibroblasts by binding studies and RT-PCR analysis, which confirmed that no progesterone receptors and mRNA are present in these cells (Pedersen et al. 1996).

Since the progesterone receptor antagonist ZK114043 (Li et al. 1995) did not relieve the inhibitory action of progesterone on aromatase induction, an action of progesterone via the progesterone receptor can be excluded.
Our experimental data thus provide independent evidence against the existence of functional progesterone receptors in human adipose tissue, especially in the adipose fibroblasts.

Glucocorticoid receptors are readily detectable in human adipose tissue, and binding of progesterone to the glucocorticoid receptor has been shown previously (Xu et al. 1990). The inhibitory potential of progesterone in our experimental system depends on the concentrations of cortisol used, indicating competition for the glucocorticoid receptor between these steroid hormones. Whereas cortisol binding results in a transcriptionally active receptor, progesterone binding appears to be unable to generate an active receptor. A previous study has found that progesterone (about $50 \mathrm{nM}$ ) had no effect on aromatase 
Table 1 Progesterone action is not blocked by an anti-progestin. Adipose fibroblasts were induced for $24 \mathrm{~h}$ with $1 \mu \mathrm{M}$ cortisol and $0.5 \mathrm{nM}$ PDGF-BB (PDGF) in the absence or presence of $1 \mu \mathrm{M}$ progesterone and/or $1 \mu \mathrm{M}$ of the pure anti-progestin ZK114043. The activities observed vary considerably between individual preparations of cells and appear to be due to unknown traits. Therefore data are presented as relative aromatase activities compared with those activities measured in the presence of cortisol and PDGF-BB. Under these conditions, the activities observed were in the range $5-30 \mathrm{pmol} / 6 \mathrm{~h}$ per protein. Results are given as means \pm S.E.M. from three preparations of cells assayed in duplicate.

\begin{tabular}{lc} 
Treatment of cells & $\begin{array}{c}\text { Relative aromatase activity } \\
\text { (\% of PDGF+cortisol) }\end{array}$ \\
PDGF+ cortisol & $100 \cdot 0 \pm 4 \cdot 4$ \\
PDGF+ cortisol + progesterone & $46 \cdot 4 \pm 4 \cdot 1$ \\
PDGF+ cortisol + ZK114043 & $76 \cdot 3 \pm 9 \cdot 2$ \\
PDGF+ cortisol + progesterone+ZK114043 & $22 \cdot 2 \pm 3 \cdot 3$ \\
\hline
\end{tabular}

Differences between individual treatment groups are significant $(P<0 \cdot 05)$ as determined by ANOVA and Student-Newman-Keuls all pairwise multiple comparison.

induction in adipose fibroblasts in the presence of serum and $250 \mathrm{nM}$ dexamethasone (Lueprasitsakul \& Longcope 1990). However, this does not disagree with our results, and allows us to predict that even higher progesterone concentrations will be necessary for competition in the presence of the high-affinity ligand dexamethasone.

Glucocorticoid and progesterone receptors bind to the identical consensus sequence, and it has been shown that induction of gene expression by these hormones in target cells is dependent on the expression of their specific receptor (Strahle et al. 1989). Competition for and inactivation of the glucocorticoid receptor by progesterone in adipose fibroblasts would offer an additional possibility for differential regulation of gene expression by steroids in these cells, which could not be the case if progesterone receptors were present. In this view, the absence of progesterone receptors enables progesterone to inhibit glucocorticoid-dependent aromatase induction.

Serum glucocorticoid concentrations exhibit marked circadian alterations, ranging from $0-0 \cdot 17 \mu \mathrm{M}$ during the night to $0 \cdot 22-0 \cdot 7 \mu \mathrm{M}$ peak concentrations. Therefore it seems reasonable to assume that our data obtained in the presence of $0 \cdot 1 \mu \mathrm{M}$ cortisol are close to physiological levels for most individuals for at least $12 \mathrm{~h}$ a day. In the presence of $0 \cdot 1 \mu \mathrm{M}$ cortisol, $100 \mathrm{nM}$ progesterone caused almost complete inhibition of glucocorticoid-dependent aromatase induction, whereas $10 \mathrm{nM}$ produced roughly $50 \%$ inhibition (see Fig. 1 B). The former would apply only to late pregnancy, whereas the latter would apply to the luteal phase of premenopausal women, in which 6-60 nM progesterone is found. These considerations suggest that, in premenopausal women, progesterone is able partially to suppress glucocorticoid-dependent aromatase induction. This may explain the increase in adipose tissue aromatase activity in postmenopausal women (Hemsell et al. 1974). In addition, an inverse correlation between progesterone concentration and aromatase activity in adipose tissue has been reported (Newton et al. 1986), further supporting that notion. Taken together, our results provide evi- dence that progesterone directly inhibits glucocorticoiddependent aromatase induction and support the hypothesis that progesterone plays an important role in the regulation of adipose tissue aromatase activity in vivo.

\section{Acknowledgements}

We thank Dr Marita Eisenmann-Klein for the samples of human breast adipose tissue, Christian Kramheller for the microsomes and Dr Jennifer-Maria Ortíz for critical reading of the manuscript. We also gratefully acknowledge the gift of ZK114043 from Dr Karsten Parczyk, Schering AG, Berlin. This work was supported by a grant from the Deutsche Forschungsgemeinschaft (DFG).

\section{References}

Ackerman GE, Smith ME, Mendelson CR, MacDonald PC \& Simpson ER 1981 Aromatization of androstenedione by human adipose tissue stromal cells in monolayer culture. Journal of Clinical Endocrinology and Metabolism 53 412-417.

Bergmeyer HU \& Bernt E 1974 Lactat-Dehydrogenase: UV-Test mit Pyruvat und NADH. In Methoden der Enzymatischen Analyse, pp 607-612. Ed HU Bergmeyer. Weinheim: Verlag Chemie.

Bradford MM 1976 A rapid and sensitive method for the quantitation of microgram quantities of protein utilizing the principle of protein-dye binding. Analytical Biochemistry 72 248-254.

Brönnegard M, Ottosson M, Böös J, Marcus C \& Björntorp P 1994 Lack of evidence for estrogen and progesterone receptors in human adipose tissue. Journal of Steroid Biochemistry and Molecular Biology 51 275-281.

Cole PA \& Robinson CH 1990 Conversion of 19-oxo[2 beta-2H] androgens into oestrogens by human placental aromatase. An unexpected stereochemical outcome. Biochemical Journal 268 $553-561$.

Evans CT, Corbin CJ, Saunders CT, Merrill JC, Simpson ER \& Mendelson CR 1987 Regulation of estrogen biosynthesis in human adipose stromal cells. Effects of dibutyryl cyclic AMP, epidermal growth factor, and phorbol esters on the synthesis of aromatase cytochrome P-450. Journal of Biological Chemistry 262 6914-6920.

Harada N, Utsumi T \& Takagi Y 1993 Tissue-specific expression of the human aromatase cytochrome P-450 gene by alternative use of 
multiple exons 1 and promoters, and switching of tissue-specific exons 1 in carcinogenesis. Proceedings of the National Academy of Sciences of the USA 90 11312-11316.

Hemsell DL, Grodin JM, Brenner PF, Siiteri PK \& MacDonald PC 1974 Plasma precursors of estrogen. II. Correlation of the extent of conversion of plasma androstenedione to estrone with age. Journal of Clinical Endocrinology and Metabolism 38 476-479.

Kellis JTR \& Vickery LE 1987 Purification and characterization of human placental aromatase cytochrome P-450. Journal of Biological Chemistry 262 4413-4420.

Li M, Spitzer E, Zschiesche W, Binas B, Parczyk K \& Grosse R 1995 Antiprogestins inhibit growth and stimulate differentiation in the normal mammary gland. Journal of Cell Physiology 164 1-8.

Lueprasitsakul P \& Longcope C 1990 Aromatase activity of human adipose tissue stromal cells: effects of thyroid hormones and progestogens. Proceedings of the Society for Experimental Biology and Medicine 194 337-341.

MacDonald PC, Edman CD, Hemsell DL, Porter JC \& Siiteri PK 1978 Effect of obesity on conversion of plasma androstenedione to estrone in postmenopausal women with and without endometrial cancer. American Journal of Obstetrics and Gynecology 130 448-455.

Mahendroo MS, Mendelson CR \& Simpson ER 1993 Tissue-specific and hormonally controlled alternative promoters regulate aromatase cytochrome P450 gene expression in human adipose tissue. Journal of Biological Chemistry 268 19463-19470.

Mendelson CR, Cleland WH, Smith ME \& Simpson ER 1982 Regulation of aromatase activity of stromal cells derived from human adipose tissue. Endocrinology 111 1077-1085.

Mendelson CR, Corbin CJ, Smith ME, Smith J \& Simpson ER 1986 Growth factors suppress and phorbol esters potentiate the action of dibutyryl adenosine $3^{\prime}, 51^{\prime}$-monophosphate to stimulate aromatase activity of human adipose stromal cells. Endocrinology 118 968-973.

Meyer AS 1955 Conversion of 19-hydroxy-delta4-androstene-3, 17-dione to estrone by endocrine tissue. Biochimica et Biophysica Acta 17 441-442.

Newton CJ, Samuel DL \& James VH 1986 Aromatase activity and concentrations of cortisol, progesterone and testosterone in breast and abdominal adipose tissue. Journal of Steroid Biochemistry $\mathbf{2 4}$ 1033-1039.

Pedersen SB, Fuglsig S, Sjogren P \& Richelsen B 1996 Identification of steroid receptors in human adipose tissue. European Journal of Clinical Investigation 26 1051-1056.
Peterson GL 1983 Determination of total protein. In Methods in Enzymology, vol. 91, pp 95-119. Eds SP Colowick \& NO Kaplan. London: Academic Press.

Rebuffe-Scrive M, Brönnegard M, Nilsson A, Eldh J, Gustafsson J-A \& Björntorp P 1990 Steroid hormone receptors in human adipose tissue. Journal of Clinical Endocrinology and Metabolism 71 1215-1219.

Richards JS 1994 Hormonal control of gene expression in the ovary. Endocrine Reviews 15 725-751.

Sambrook J, Fritsch EF \& Maniatis T 1989 Molecular Cloning, edn 2. Cold Spring Harbor: Cold Spring Harbor Laboratory Press.

Schmidt M \& Löffler G 1994 Induction of aromatase in stromal vascular cells from human breast adipose tissue depends on cortisol and growth factors. FEBS Letters 341 177-181.

Schmidt M \& Löffler G 1997 RU486 is a potent inhibitor of aromatase induction in human breast adipose tissue stromal cells. Journal of Steroid Biochemistry and Molecular Biology 60 197-204.

Simpson ER, Ackerman GE, Smith ME \& Mendelson CR 1981 Estrogen formation in stromal cells of adipose tissue of women: induction by glucocorticosteroids. Proceedings of the National Academy of Sciences of the USA 78 5690-5694.

Simpson ER, Merrill JC, Hollub AJ, Graham Lorence S \& Mendelson CR 1989 Regulation of estrogen biosynthesis by human adipose cells. Endocrine Reviews 10 136-148.

Simpson ER, Mahendroo MS, Means GD, Kilgore MW, Hinshelwood MM, Graham Lorence S, Amarneh B, Ito Y, Fisher CR, Michael MD et al 1994 Aromatase cytochrome P450, the enzyme responsible for estrogen biosynthesis. Endocrine Reviews $\mathbf{1 5}$ 342-355

Strahle U, Boshart M, Klock G, Stewart F \& Schultz G 1989 Glucocorticoid- and progesterone-specific effects are determined by differential expression of the respective hormone receptors. Nature 339 629-632.

Walter K \& Schütt C 1974 Alkalische Phosphatase in Serum. In Methoden der Enzymatischen Analyse, pp 893-897. Ed HU Bergmeyer. Weinheim: Verlag Chemie.

Xu XF, Hoebeke J \& Björntorp P 1990 Progestin binds to the glucocorticoid receptor and mediates antiglucocorticoid effect in rat adipose precursor cells. Journal of Steroid Biochemistry and Molecular Biology 36 465-471.

Received 1 December 1997 Accepted 22 April 1998 